\title{
Ludwig Kleinwaechter
}

Ludwig Kleinwaechter was an Austrian patriot who served his country loyally and with distinction during the extremely difficult and crucial period of transition from empire to a small, neutral nation. Born in Czernowitz in 1882, the son of a distinguished economist from Prague, he was one of the last of a rapidly vanishing generation of Austrians whose personality and character had been formed by the multinational empire. Although he was devoted to the cosmopolitan traditions of the "greater Austria" to which he continued to feel bound emotionally during his whole lifetime, he became a most loyal public servant of the First and, finally, of the Second Austrian Republic. Kleinwaechter was firmly convinced of the paramount importance of a free and independent Austria for the balance of power and for the preservation of peace in $\mathrm{Eu}-$ rope. Only once did his public career come to an abrupt halt: when German troops marched into Austria in 1938 and Austria's independence was temporarily abolished. Together with Leopold Figl, who was to become chancellor after the war, Kleinwaechter was one of the first Austrians to be sent to a German concentration camp.

Kleinwaechter had a wide range of diplomatic experiences. He served in Petrograd, Rome, and Ottawa, and with the foreign ministry in Vienna, but his most important diplomatic assignment was to the United States, a country towards which he felt a particular personal attachment. The liberal traditions and cosmopolitan character of the American continent always held a special attraction for him. He had the greatest respect for and boundless confidence in the humanistic qualities of American civilization, which he defended with eloquence and vigor against European detractors. Indeed, he felt more at home in the vast spaces of the United States than within the narrow confines of the European continent.

In 1917 Kleinwaechter was stationed in Washington, where he witnessed the final stages of the breakdown of diplomatic relations between the United States and the Austro-Hungarian empire. He was convinced that the empire would have survived, even at that late hour, had the imperial government in Vienna loosened its bonds with Germany. The Austrian embassy, headed by the last imperial ambassador to the United States Adam Tarnowski, was located on Connecticut Avenue, close to the residence of Robert Lansing, who was secretary of state. Several times, so Kleinwaechter told me, Lansing asked Ambassador Tarnowski to spend a quiet evening at his residence to discuss, in most serious terms, the future of Austria and the postwar map of Europe. During these conversations Lansing beseeched the ambassador to 
induce his government to give up its alliance with Germany and make a separate peace with the Entente Powers. Kleinwaechter, who was a discreet but keen observer, watched these developments with anxiety. $\mathrm{He}$ left Washington with a heavy heart when diplomatic relations were broken between Austria-Hungary and the United States, foreshadowing the end of the multinational empire which he loved so dearly.

It is a great loss to historical research that Kleinwaechter, whose career spanned half a century of critical developments in Central Europe, did not leave biographical notes or record his remembrances of historical events in a systematic way. His sense of discretion prevented him from disclosing more than occasional anecdotes.

When the Austrian government decided in 1946 to send political representatives to the capitals of the four occupying powers, Kleinwaechter was a natural choice for the Washington post. He organized Austria's first postwar mission in Washington under extraordinarily difficult circumstances. There was no residence, no chancery, no staff, no typewriter, no stationery, and no money (except a state department loan of some $\$ 10,000$ ) available to set up what came to be for the next ten years Austria's most important mission. Shortly after his arrival in the capital, K leinwaechter was scheduled to go to Atlantic City to attend an UNRRA conference of vital importance for Austria's food supply. He almost missed his train at the union station because he had to procure another "loan" from the state department to pay for his trip to Atlantic City. Such were the privations and tribulations of Austria's first postwar representative in the United States.

Kleinwaechter died at the biblical age of 91 . In addition to being an unusually able diplomat, he was a most likeable human being, endowed with an admirable sense of humor. An entire generation of postwar Austrian diplomats owe their professional training and education to Kleinwaechter, a grand seigneur in the best tradition of the old Austrian civil service. The example of his wisdom and his noble spirit are the legacy he left for future Austrian diplomats.

Federal Chancellery (Vienna)

Hans J. Thalberg, Ambassador 